\title{
THE SWEDISH GOVERNMENT FIRST WITHDREW SUPPORT FOR THE MEDITERRANEAN INSTITUTES, THEN CHANGED ITS MIND
}

In September Sweden acquired a new government. In its first budget it proposed to end the financial support for Sweden's three Mediterranean institutes. The budget proposal was presented with no advance warning. There was no support for it among officials, researchers or educators. The proposal was drawn up without any consultation with those who have the expert knowledge and was carried through in the last-minute political negotiations about the budget. There was thus no consequence analysis of the proposal.

The proposal was met with immediate harsh criticism. There was unanimous condemnation of the content of the budget proposal from the scholarly community and in the press, radio and television.

Sweden's Mediterranean institutes in Rome, Athens and Istanbul are venerable institutes of research and education. For many years they have provided outstanding conditions for Swedish research and teaching. The work of the institutes comprises subjects such as archaeology, art history, languages, literature, architecture, heritage preservation and conservation, history, philosophy, political science and comparative religion. With the government's proposal, researchers in the humanities and social sciences would no longer have access to these international environments. Students would lose the unique educational possibilities offered by these institutes.

For Swedish archaeological research in Italy, Greece and Turkey, the institutes are essential. They obtain permits, manage contacts with local authorities, and provide local knowledge, research archives, specialist libraries, and solutions to administrative and practical problems. It would 
not be possible to carry on research and education in the Mediterranean countries as today if the state support for the institutes were withdrawn.

Those who know about the roles and functions of the institutes understood immediately that the proposal had not been thought through. And the massive criticism of the proposal had an effect. A few weeks after it had been announced, the government changed its mind and withdrew the proposal. Yet even though this particular proposal has been withdrawn, the idea is not dead. The financial support is to be subject to further inquiry.

It is good that the proposal was withdrawn. And an inquiry is needed. But this should not be in order to balance the work of the institutes in relation to badly prepared budget proposals. Instead there is an opportunity here to take constructive action to review the existing mission of the institutes and assign extended tasks to these international platforms for scholarly meetings and education.

Building up networks and establishing trust takes time. It requires long-term efforts and cultural competence. The institutes are more than places of research and education. They possess a cultural capital that can be used to pursue the Swedish universities' stated strategies for internationalization. There is extensive knowledge in the scholarly community concerning how this can be done. The toing and froing about budget proposals and financing this autumn show how vulnerable something important can be. It also shows how crucial the critical public debate is in situations like this.

The Swedish Archaeological Society will be following this matter closely and will keep readers of Current Swedish Archaeology informed about how it develops. Updates are available through: https://sv-se.facebook.com/arkeologiskasamfundet.

Anders Högberg, Linnaeus University

Editor of Current Swedish Archaeology, and co-chairman of the Swedish Archaeological Society 